RELATO DE PRÁTICA: PRÊMIO VICTOR CIVITA EDUCADOR NOTA 10

\title{
Não é fácil premiar com justiça
}

GABRIEL GRosSI

REgINA SCARPA*

0 que nossas crianças devem, de fato, aprender na escola?

É isso o que seus professores estão ensinando?

Estas foram as principais questões que nortearam a seleção dos 3.851 trabalhos inscritos para o Prêmio Victor Civita Educador Nota 10, em 2006. Em outras palavras, procurou-se buscar o que cada professor e cada professora efetivamente ensinaram e como se deu esse processo.

O importante é pensar: para que serve um prêmio na área da Educação? Ao longo de todos esses anos, ficou muito claro, para nós, que o Prêmio Victor Civita tem três objetivos principais:

- Valorizar o bom professor e mostrar a importância da profissão de educador

Sobretudo porque o Prêmio tem ampla divulgação, tanto pela revista Nova Escola quanto pela rede pública de televisão, graças a uma parceria com a TV Cultura, de São Paulo;

- Revelar a situação real da Educação brasileira ano após ano

Por meio da leitura e análise dos projetos, é possível identificar claramente o que está sendo realizado nas escolas, principalmente nas redes públicas, que respondem pelo maior número de inscrições;

- Divulgar boas experiências, com ênfase para o fato de que elas podem servir de referência para os professores

Ao publicar os perfis dos professores vencedores e os relatos de seus trabalhos, procura-se ser indutor de boas práticas pedagógicas.

Nesse contexto, um elemento é fundamental: escoIher bem a equipe de selecionadores para garantir que eles tenham condições de julgar adequadamente se os

* Gabriel Grossı é diretor de redação da revista Nova Escola. REGINA SCARPA é coordenadora pedagógica da Fundação Victor Civita. professores inscritos realizaram um trabalho consistente com os alunos. Alguns dos critérios utilizados em 2006 para a escolha dos selecionadores foram: a familiaridade com a escola pública e o conhecimento didático de sua área de atuação.

\section{A importância da seleção}

Como todos os projetos que adquirem relevância, o Prêmio Victor Civita é hoje uma atividade que consome o ano todo, praticamente sem interrupção. Terminada a festa de entrega dos troféus, já é hora de pensar se é necessário fazer algum tipo de alteração no regulamento, afinar as parcerias e preparar o material para divulgar, na revista Nova Escola, tanto os trabalhos vencedores quanto as chamadas para o ano seguinte.

Mas nada se compara à tarefa que cabe aos selecionadores. Em 2006, tivemos o privilégio de poder contar com um grupo de 16 professores e formadores de professores nessa equipe, que trabalha durante pouco mais de um mês na leitura e análise dos projetos inscritos.

Este processo tem várias etapas. Na primeira leitura dos textos, há uma separação quase natural do "joio" e do "trigo" - uma pré-seleção. São visíveis os projetos que não têm um propósito claro de ensinar conteúdos relevantes. É nessa hora que os selecionadores começam a observar se os critérios gerais para a classificação dos trabalhos foram atendidos:

- o trabalho é modesto e seus objetivos e metodologias adequados ao que se propôs realizar;

- há intencionalidade do trabalho desenvolvido pelo professor. A metodologia reflete uma ação planejada;

- apresenta um conteúdo relevante e pertinente à faixa etária e ajuda os alunos a avançarem na sua compreensão;

- as estratégias metodológicas utilizadas podem ser tomadas como referência para realização de proje- 
tos semelhantes por outros professores que conhecerem este trabalho;

- demonstra a atuação dos alunos e há, em sua avaliação, indicadores de aprendizagem.

Em uma segunda análise, mais minuciosa, consideram-se os critérios específicos da área para a seleção e os potenciais vencedores. Nesse momento, é comum pedir a ajuda dos colegas.

Por exemplo, um trabalho sobre meio ambiente sempre será lido, no mínimo, pelos responsáveis por fazer a triagem de Geografia e também pelos de Ciências. Dia após dia, no contato permanente e na troca de idéias, os selecionadores vão estreitando os critérios para definir o que é um bom concorrente e por que ele deve ser premiado. A coordenação pedagógica participa lendo e discutindo os trabalhos com os selecionadores.

$\mathrm{Na}$ reta final, temos uma lista com algo entre 50 e 80 candidatos a Educador Nota 10. É nesse momento que os selecionadores pedem aos inscritos todo o material utilizado em classe e também o que foi desenvolvido pelos estudantes, às vezes, pacotes enormes com a produção de textos, desenhos, fitas de vídeo, CD-ROMs etc. Após a análise desse material, é hora de conversar por telefone com os candidatos e esclarecer dúvidas, checar se o professor efetivamente domina o que foi feito em sala de aula e garante que sua turma construiu efetivamente aprendizagens relevantes. Uma das professoras vencedoras deste ano disse ter se sentido argüida pelo selecionador como numa defesa de tese.

Nessa etapa, todos os selecionadores lêem os trabaIhos indicados por seus colegas, acompanhados de um questionário contendo os seguintes itens:

- Por que considerou este trabalho relevante? Que aspectos lhe chamaram a atenção?

- Que expectativas de aprendizagem o professor (a) tinha? 0 que os alunos aprenderam? Outros resultados foram alcançados?

- Os conteúdos estavam compatíveis com as necessidades de aprendizagem dos alunos? Justifique.

- O desenvolvimento do trabalho ocorreu de forma compatível com seus objetivos e conteúdos? Comente.

- O professor valorizou a interação entre os alunos como fator de aprendizagem? Em que situações?

- E o professor, aprendeu algo? Dê a sua opinião.

- Em que aspectos o trabalho poderia ser melhor? Que devolutiva você daria ao professor no sentido de contribuir com a sua formação profissional?
Esta troca entre os selecionadores, este debate que se estabelece no dia-a-dia criam um sentimento fascinante de responsabilidade coletiva, que culmina com uma grande reunião para definir os dez finalistas. Em 2006, ela consumiu dois dias inteiros de trabalho, sob a liderança da coordenação pedagógica da Fundação Victor Civita, e com a participação de jornalistas da Nova Escola.

Nesse encontro, regado a muito café, água, suco, pão de queijo e biscoitos, os selecionadores apresentam uma síntese sobre tudo o que cada um leu, com os destaques positivos e negativos, algo que retrate o "estado da arte" da área de conhecimento analisada. É impossível, diante de tanta informação e reflexão, não aprender com esse gigantesco panorama da Educação no Brasil.

Esse momento ajuda a localizar os trabalhos indicados em relação aos trabalhos recebidos. Tudo para garantir que os vencedores sejam os melhores do ponto de vista daquilo que foi analisado e do que os alunos aprenderam.

\section{0 projeto, ao vivo.}

Esse panorama ganha novas cores no mês de agosto, quando os jornalistas e fotógrafos vão, finalmente, conhecer ao vivo os dez finalistas. Eles são os primeiros a visitar pessoalmente a escola em que esses professores trabalham, entrar em suas casas, descobrir como eles fazem (quase sempre em condições bem distantes das ideais) para ensinar mais e melhor.

É óbvio que, vez ou outra, na história do prêmio, apareceram pequenos problemas. Um trabalho que parecia muito consistente revela-se mais frágil. Um professor, que se mostrava confiante no relato escrito, mostra-se mais tímido e inseguro na conversa pessoal. De certa forma, esse parece ser um risco difícil de evitar por causa de uma polêmica que sempre pairou sobre a história do Prêmio Victor Civita: afinal, estamos premiando os Educadores Nota 10 ou os trabalhos que eles inscreveram?

Por isso, já há quatro anos, todos esses professores também são avaliados quando chegam a São Paulo para a grande festa de premiação, no mês de outubro. Todos têm a obrigação de apresentar seus projetos - não apenas aos outros vencedores, como também para um grupo muito selecionado de especialistas, o júri que, até 2006, tinha por tarefa escolher o Educador do Ano. 
